\title{
Occurrence of Fusarium oxysporum (Schlecht. Emend. Snyder \& Hansen) Causing Pod Blight of Soybean (Glycine max L.) and Its Suitable Management with Native Trichoderma spp. in Manipur, India
}

\author{
C. Lalhruaitluangi", B. Sinha and Tusi Chakma \\ Department of Plant Pathology, College of Agril., CAU, Imphal-795004, Manipur, India \\ *Corresponding author
}

\begin{tabular}{|c|}
\hline Keywords \\
\hline $\begin{array}{l}\text { Fusarium oxysporum, } \\
\text { PCR, Pod blight, } \\
\text { Trichoderma, Soybean }\end{array}$ \\
\hline Article Info \\
\hline $\begin{array}{l}\text { Accepted: } \\
04 \text { October } 2018 \\
\text { Available Online: } \\
10 \text { November } 2018\end{array}$ \\
\hline
\end{tabular}

A B S T R A C T

During 2015-16 survey was conducted in six different soybean growing areas of Manipur, India. The survey revealed that the maximum mean pod blight intensity was at Thoubal $(21.23 \%)$ and minimum $(13.82 \%)$ at Andro Research Farm, CAU. Fusarium oxysporum was isolated and identified by morphological characteristics and gene sequencing, MF512000. The pathogen was found to be the causal organism of pod blight of soybean. Total genomic DNA of the fungal cultures was extracted by using HiPurA DNA isolation Kit (HiMedia, India). PCR amplification of internal transcribed spacer regions was done using specific ITS1 and ITS4 primers and was confirmed by $1.2 \%$ agarose gel electrophoresis which produced a fixed region length of approximately $600 \mathrm{bp}$ for Fusarium oxysporum. Effects of volatile compounds produced by the Trichoderma spp. against Fusarium oxysporum ranged from 26.27-42.40 per cent. The effects of non-volatile compounds produced by Trichoderma spp. ranged from $20.39-43.52$ per cent at $7.5 \% \mathrm{v} / \mathrm{v}$ concentration and 29.41-53.72 per cent at $15 \% \mathrm{v} / \mathrm{v}$. In vivo study of isolates of Trichoderma spp. under field trials as seed treatment (@5g/kg seed) with foliar spraying (@ $5 \mathrm{~g} / \mathrm{l}$ of water) at 40 days after planting of water showed considerable reduction in disease incidence and increased production over control plot. The isolate $T$. harzianum (KU933468) showed highest yield in field trial (17.44 q/ha).

\section{Introduction}

Soybean (Glycine $\max$ L.) is the most important oilseed crop for its excellent protein $(42-45 \%)$, oil (22\%) and starch content $(21 \%)$.

It is a good source of vitamin-B complex, thiamine and riboflavin. Soybean protein is rich in valuable amino acids like Lysine (5\%) in which, most of the cereals are deficient. Its oil is the largest component of the world's protein. It grows well in warm and moist climate and water logging is injurious to the crops (Sarabhoy and Agarwal, 1983).

In India, area, production and yield during 2015-2016 were 11.40 million per hectares, 7.38 million metric tonnes and 0.65 metric tonnes per hectare respectively (Anonymous, 2016). Soybean growing major states in the country are Madhya Pradesh, Maharashtra, Andhra Pradesh, Tamil Nadu, Rajasthan, Gujarat, Uttar Pradesh, Punjab and Haryana (Bhatnagar, 1997). Yield losses due to 
Fusarium rot of soybean were estimated to be over 7300 metric tonnes $(2.5 \%)$ in Canada (Wrather et al., 2001).

In spite of its phenomenal increase in area and production, its productivity remains low due to lack of quality seeds, various diseases and insect-pests. More than 100 plant pathogens have been reported to affect soybean, but among them very few are economically important causing yield losses to the tune of 12-20 per cent (Mittal et al., 1993). Soybean diseases cause reductions in yield to the tonnes of 10 to $30 \%$ in most of the areas (Sinclair, 1992). So far, not much previous research have been done regarding pod blight of soybean and its management in this region. Therefore, the present study deals with the study of occurrence pod blight of soybean caused by Fusarium oxysporum in some soybean growing areas of Manipur and to find suitable management with native Trichoderma spp.

\section{Materials and Methods}

\section{Soybean disease survey}

A detail survey was conducted at different valley areas of Manipur viz., Andro Research Farm (CAU), Iroisemba (College campus), Imphal East, Thoubal, Bishnupur and Imphal West at different days intervals $(30,60 \& 90$ DAP) on intensity of pod blight of soybean. Disease severity was recorded by random sampling and diseased samples were collected separately for in-vitro study. Disease severity was assessed based on 0-9 scale [0 (No discolouration), 1 (1\% area covered with discolouration), 3 (1.1-10\% area covered with discolouration), 5 (10.1-25\% area covered with discolouration), $7 \quad(25.1-50 \%$ area covered with discolouration), 9 (25.1-55\% area covered with discolouration)]. Percentage of disease index was calculated by following formula;
Per cent Disease Index $=\frac{\text { sum of all numerical ratings }}{\text { Number of leaf sample } \mathrm{x} \text { Maximum disease grade }} \times 100$

\section{Fungal identification and pathogenicity}

Disease samples collected from the surveyed field were cutted into small pieces of 2-3 mm size. The pieces were surface sterilized with $0.1 \%$ sodium hypochlorite solution for 1 minute and then rinsed with sterile distilled water. The sterilized pieces were then inoculated on potato dextrose agar (PDA) and incubated at $25 \pm 2{ }^{0} \mathrm{C}$. The fungus was identified in the laboratory, Department of Plant Pathology, College of Agriculture, CAU, Imphal. Pure culture was maintained on freshly prepared PDA slants inside refrigerator and periodically sub cultured to fresh medium during the investigation.

\section{Pathogenecity test}

The pathogenicity test of the isolated fungi was conducted by following the Koch's postulate.

\section{Molecular characterization}

The pure culture of the fungus was grown on Potato Dextrose Broth $50 \mathrm{ml}$ in $100 \mathrm{ml}$ conical flask at temperature of $27 \pm 2^{\circ} \mathrm{C}$ in BOD incubator. After 3-4 days of fungal growth, the mycelia of all the isolates were harvested by filtering. The mass of mycelium thus obtained was pressed with blotting paper and dried slightly and used directly for DNA isolation. DNA of the fungal culture was isolated using the HiPurA DNA isolation Kit (HiMedia, India).

\section{PCR amplification and electrophoresis}

The above extracted genomic DNA of fungal isolates was amplified using ITS-1 primer (5, TCC GTA GGT GAA CCT GCC G3' (5V)) and ITS-4 primer (5' TCC TCC GCT TAT 
TGA TAT GC 3'). The forward (ITS-1) and reverse (ITS-4) primers used in the PCR reactions performed in this study were developed by White et al., (1990) and designed to amplify the ITS region of the rRNA operon. The PCR amplification was carried out in $0.2 \mathrm{ml}$ PCR tubes with $25 \mu \mathrm{l}$ reaction volumes by using PX2 thermal cycler (Thermo Electron Corporation) and with a temperature profile standardized for gene amplification.

The electrophoresis of the amplified DNA was carried out in $1.2 \%$ agarose gel stained with ethidium bromide. To each PCR amplified sample, $1 \mu 1$ of $6 \mathrm{X}$ loading dye was added.

A DNA ladder marker (100bp) was used as standard and the gel was run at $70 \mathrm{~V}$ until the loading dye reached the gel front. The amplified DNA was viewed under the gel documentation system (BIORAD, Molecular Imager Gel DOCTM XR).

\section{In vitro antagonistic potential of some isolates of Trichoderma}

Some potent isolates of Trichoderma spp. viz., $T$. ovalisporum (KU904456), T. harzianum (KU933468), T. atroviride (KU933472), T. harzianum (KU933474), T. asperellum (KU933475), Hypocrea lixii (KX0113223) used in this study were collected from Department of Plant Pathology, COA, CAU, Imphal and were evaluated against Fusarium sp. through dual culture technique, production of non-volatile and volatile by Dennis and Webster, (1971a, 1971b). The radial mycelial growth of test pathogen was recorded daily and compared with control plates. The radial mycelial growth of test pathogen and antagonist were measured periodically and the per cent inhibition of mycelial growth of test pathogen by antagonists was calculated as per formulae adopted by Garcia (1991) as:
Per cent Inhibition of Radial Growth (\% IRG) $=100\left[\left(\mathrm{R}_{1}-\mathrm{R}_{2}\right) / \mathrm{R}_{1}\right]$, where,

$\mathrm{R}_{1}$ - the farthest radial distance grown by the pathogen in the direction of the antagonist.

$\mathrm{R}_{2}$ - the distance grown on a line between inoculation positions of the pathogen and antagonist.

\section{Seed priming with bioagents}

Biopriming of soybean seeds was done for 1 hour by potent isolates of Trichoderma spp. The germination of seeds was observed periodically and the root length, shoots length were measured. The vigour index of respective crop seedlings were calculated on the basis of root and shoot length as follows:

Vigour index of seedlings $=[$ Root length $(\mathrm{cm})$ + shoot length $(\mathrm{cm})] \mathrm{x}$ germination $(\%)$.

\section{In vivo efficacy of Trichoderma isolates}

Six potent isolates of Trichoderma were evaluated against Fusarium sp. under field condition. Field experiment to study the efficacy of Trichoderma isolates against pod blight of soybean caused by Fusarium sp. was conducted at College of Agriculture, Central Agricultural University, Imphal during 201516. Field trials were taken up in randomized block design (RBD) with three replications. Plot sizes were $2 \mathrm{~m} \times 2 \mathrm{~m}$ in all the trials. Soybean variety JS-335 (Jawahar Soybean335) was used as test plants. Untreated plots served as control. Disease incidence was calculated at 15 days interval at 30, 60 and 90 days after planting. Observation was recorded on germination percentage, canopy, number of pods per plant and the numbers of seeds per pod. Pods of soybean were harvested and pod yield of each plot were taken and converted into quintal per hectare. The six potent isolates of Trichoderma spp. and one chemical fungicide were used. 


\section{Results and Discussion}

Incidence of pod blight of soybean in farmer's field

Field survey was conducted at six different areas of Manipur viz., Andro Research Farm (CAU), Iroisemba (College campus), Imphal East, Thoubal, Bishnupur and Imphal West for natural incidence of pod blight of soybean during kharif season 2015-16 at regular interval i.e. 30DAP, 45DAP, 60DAP, 75DAP, 90DAP and results are presented in table 1. Results indicated that the average incidence of pod blight of soybean ranged from 13.82 per cent to 21.23 per cent. The highest average disease incidence was found at Thoubal (21.23 per cent) and lowest at Andro Research Farm, CAU (13.82 per cent). The present findings are in accordance with the findings of Chavan and Dhutraj (2017) who conducted a survey studies during 2011-2012 throughout all the eight districts of the Marathwada region in Maharashtra during kharif season and found that during kharif 2011, average pod blight intensity in the eight districts surveyed ranged from 27.75 to 38.88 per cent and during kharif 2012 , average disease intensity ranged from 29.85 to 38.98 per cent respectively.

\section{Molecular characterization}

Total genomic DNA of the isolated purified fungal cultures was extracted by using the HiPurA DNA isolation Kit (HiMedia, India). PCR amplification of internal transcribed spacer region was done using specific ITS1 and ITS4 primers for Fusarium sp. and approximately 600bp were amplified using PCR and were confirmed by $1.2 \%$ agarose gel electrophoresis which was shown in Figure 1. Devi et al., (2016) reported that ITS region was successfully amplified from DNA from all $F$. oxysporum strains by the fungal-specific universal primer pairs ITS1-ITS4.
In vitro antagonistic potential of some isolates of Trichoderma spp

In vitro antagonistic potential of isolates of Trichoderma spp. were evaluated against Fusarium sp. through production of volatile and non-volatile compounds.

\section{Effect of volatile compounds}

The effects of volatile compounds produced by Trichoderma spp. against Fusarium sp. were examined and results are presented in table 2. Among the six isolates of Trichoderma spp. tested, maximum percentage inhibition of 42.74 per cent was recorded by isolate $T$. harzianum (KU933474) and minimum percentage inhibition of 26.27 per cent was recorded by isolate $T$. asperellum (KU933475). The inhibition percentage of other isolates viz., T. harzianum (KU933468), T. ovalisporum (KU904456), Hypocrea lixii (KX0113223) and T. atroviride (KU933472) were 41.17 per cent, 36.47 per cent, 28.62 per cent and 26.27 per cent respectively. The present findings are in accordance with the findings of Raza et al., (2013) who reported that strain SQR-T037 of T. harzianum produced volatile compounds that can inhibit the growth of $F$. oxysporum up to $40 \%$, while the non-volatile antifungal compounds extracted from the liquid culture significantly inhibited the growth of $F$. oxysporum.

\section{Effect of non-volatile compounds}

The effect of non-volatile compounds produced by Trichoderma spp. at two different concentrations viz., $7.5 \%(\mathrm{v} / \mathrm{v})$ and $15 \%(\mathrm{v} / \mathrm{v})$ were studied against Fusarium sp. and results are presented in table 2 . Results showed that per cent inhibition of radial growth of Fusarium sp. by six isolates of Trichoderma spp. ranged from 20.39 per cent to 43.52 per cent at $7.5 \% \mathrm{v} / \mathrm{v}$ concentration and from 36.07 per cent to 77.65 per cent at $15 \% \mathrm{v} / \mathrm{v}$ 
respectively. The inhibition percentage shown by other isolates at $7.5 \%$ were 34.11 per cent (T. harzianum - KU933468), 30.97 per cent (T. atroviride - KU933472), 22.74 per cent ( $T$. ovalisporum - KU904456), 21.96 per cent (Hypocrea lixii - KX0113223), 20.39 per cent (T. asperellum- KU933475). The inhibition percentage shown by other isolates at $15 \%$ v/v were 75.49 per cent ( $T$. harzianum KU933468), 54.51 per cent (T. atroviride KU933472), 43.52 per cent (T. ovalisporum KU904456), 40.39 per cent (Hypocrea lixii KX0113223), 36.07 per cent (T. asperellum KU933475). Altinok and Erdogan (2015) also reported that $T$. harzianum strains produced volatile and non-volatile metabolites that inhibited growth of $F$. oxysporum strains on PDA medium.

\section{Seed priming with bioagents}

Biopriming of soybean seeds was done with six potent isolates of Trichoderma spp. viz., $T$. ovalisporum (KU904456), T. harzianum (KU933468), T. atroviride (KU933472), T.harzianum (KU933474), T. asperellum (KU933475), Hypocrea lixii (KX0113223) and results are presented in table 3 . The highest root length was observed in isolate $T$. harzianum - KU933468 $(7.02 \mathrm{~cm})$ and lowest in Hypocrea lixii - KX0113223 (4.33 cm). However, in untreated control the root length was only $3.18 \mathrm{~cm}$. The highest shoot length was observed in isolate $T$. harzianum KU933468 $(1.10 \mathrm{~cm})$ lowest in Hypocrea lixii - KX0113223 $(0.80 \mathrm{~cm})$ and in control it was $0.38 \mathrm{~cm}$. Highest germination percentage was recorded in $T$. harzianum - KU933468 $(86.67 \%)$ and lowest was in T. asperellum KU933475 (46.67\%). There was only $33.33 \%$ seed germination in untreated control. The highest vigour index was observed in $T$. harzianum - KU933468 (596.82) and lowest was in $T$. asperellum- KU933475 (251.52). However, in untreated control, vigour index was 143.89. All the isolates showed significant differences of vigour index among them. The present study is supported by several researchers who have reported the biological seed treatments for protection of seed and control of pathogens causing seedling diseases (Harman et al., 1991; Bennett et al., 1992; Chet and Inbar, 1994). Seed priming is reported to eliminate toxic substances from seeds; consequently it is possible to remove pathogen from seeds which contribute to disease reduction and subsequent enhancement (Doijode, 2006) (Fig. 2).

\section{In vivo efficacy of Trichoderma isolates}

In vivo efficacy of six potent isolates of Trichoderma viz., $\quad$ T. ovalisporum (KU904456), T. harzianum (KU933468), $T$. atroviride (KU933472), T. harzianum (KU933474), T. asperellum (KU933475) and Hypocrea lixii (KX0113223) were evaluated against Fusarium sp. under field conditions during 2015-2016.

Effect of Trichoderma isolates on the yield and yield attributing characters soybean under field conditions

\section{Germination percentage}

The data on germination percentage of soybean under different treatments are presented in table 4. Results showed that the germination percentage in Carbendazim50WP treated seed was highest (91.00\%), followed by $T$. harzianum - KU933468 (87.64\%), T. harzianum - KU933474 (85.22\%), Hypocrea lixii - KX0113223 (77.74\%), T. asperellum - KU933475 (76.42\%), T. atroviride- KU933472 (75.53\%) and T. ovalisporum - KU904456 (74.60\%) respectively. In untreated plots, the germination percentage was $60.64 \%$. 
Table.1 Incidence of pod blight of soybean in different areas of Manipur during 2015-2016

\begin{tabular}{|c|c|c|c|c|c|c|}
\hline \multirow[t]{2}{*}{ Location } & \multicolumn{4}{|c|}{ Disease Incidence (\%)* } & \multirow[t]{2}{*}{ Latitude } & \multirow[t]{2}{*}{ Longitude } \\
\hline & 30DAP & 60DAP & 90DAP & $\begin{array}{l}\text { Average disease } \\
\text { incidence }\end{array}$ & & \\
\hline $\begin{array}{l}\text { 1. Iroisemba (CAU, } \\
\text { College campus) }\end{array}$ & $\begin{array}{l}4.07 \\
(2.13)\end{array}$ & $\begin{array}{l}16.66 \\
(4.14)\end{array}$ & $\begin{array}{l}38.88 \\
(6.28)\end{array}$ & $19.87(4.19)$ & $\mathrm{N}-24^{0} 78.070$ & E-093 09.674 \\
\hline 2. Imphal East & $\begin{array}{c}2.40 \\
(1.70)\end{array}$ & $\begin{array}{l}10.37 \\
(3.29)\end{array}$ & $\begin{array}{l}29.63 \\
(5.49)\end{array}$ & $14.13(3.50)$ & $\mathrm{N}-24^{0} 24.001$ & $\mathrm{E}-093^{0} 42.252$ \\
\hline 3. Thoubal & $\begin{array}{l}4.81 \\
(2.30)\end{array}$ & $\begin{array}{l}18.14 \\
(4.32)\end{array}$ & $\begin{array}{l}40.74 \\
(6.42)\end{array}$ & $21.23(4.35)$ & N- $24^{0} 35.350$ & E-094 01.489 \\
\hline $\begin{array}{l}\text { 4. Andro Research } \\
\text { Farm, CAU }\end{array}$ & $\begin{array}{c}2.96 \\
(1.84)\end{array}$ & $\begin{array}{l}11.11 \\
(3.40)\end{array}$ & $\begin{array}{l}27.40 \\
(5.28)\end{array}$ & $13.82(3.52)$ & $\mathrm{N}-24^{0} 45.827$ & E-093 03.138 \\
\hline 5. Bishnupur & $\begin{array}{l}3.70 \\
(2.05)\end{array}$ & $\begin{array}{l}16.29 \\
(4.10)\end{array}$ & $\begin{array}{l}37.40 \\
(6.16)\end{array}$ & $19.13(4.10)$ & $\mathrm{N}-24^{0} 25.927$ & $\mathrm{E}-093^{0} 43.074$ \\
\hline 6. Imphal West & $\begin{array}{c}4.44 \\
(2.21)\end{array}$ & $\begin{array}{l}17.77 \\
(4.27)\end{array}$ & $\begin{array}{l}39.99 \\
(6.36)\end{array}$ & $20.73(4.29)$ & N- $24^{\circ} 49.416$ & E-093⒌161 \\
\hline 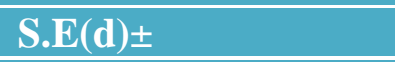 & 0.14 & 0.13 & 0.07 & 0.13 & & \\
\hline C.D (5\%) & 0.31 & 0.30 & 0.16 & 0.29 & & \\
\hline
\end{tabular}

*Mean of three replications

Values in parentheses are square root transformed values

Table.2 Effect of volatile and non-volatile compounds of Trichoderma spp. on growth of Fusarium sp.

\begin{tabular}{|c|c|c|c|c|}
\hline \multirow[t]{3}{*}{ Sl. no } & \multirow[t]{3}{*}{ Trichoderma spp. } & \multicolumn{3}{|c|}{ Percent inhibition over control* } \\
\hline & & \multirow{2}{*}{$\begin{array}{c}\text { Volatile } \\
\text { compounds }\end{array}$} & \multicolumn{2}{|c|}{ Non-volatile compounds } \\
\hline & & & $(7.5) \%$ & (15) \% \\
\hline 1. & T. ovalisporum (KU904456) & $36.47(6.08)$ & $22.74(4.80)$ & $43.52(6.63)$ \\
\hline 2. & T. harzianum (KU933468) & $41.17(6.45)$ & $34.11(5.86)$ & $75.49(8.71)$ \\
\hline 3. & T. atroviride (KU933472) & $39.60(6.33)$ & $30.97(5.60)$ & $54.51(7.42)$ \\
\hline 4. & T. harzianum (KU933474) & $42.74(6.57)$ & $43.52(6.63)$ & $77.65(8.84)$ \\
\hline 5. & T. asperellum (KU933475) & $26.27(5.16)$ & $20.39(4.56)$ & $36.07(6.04)$ \\
\hline 6. & Hypocrea lixii (KX0113223) & $28.62(5.39)$ & $21.96(4.74)$ & $40.39(6.37)$ \\
\hline \multicolumn{2}{|c|}{ S.E(d) \pm} & 0.25 & 0.36 & 0.30 \\
\hline \multicolumn{2}{|c|}{ C.D. $(5 \%)$} & 0.54 & 0.77 & 0.65 \\
\hline
\end{tabular}

*Mean of three replications

Values in parentheses are square root transformed values 
Int.J.Curr.Microbiol.App.Sci (2018) 7(11): 148-159

Table.3 Biopriming of soybean seeds with Trichoderma spp.

\begin{tabular}{|c|c|c|c|c|c|}
\hline Sl. no. & Trichoderma spp. & $\begin{array}{l}\text { Root length } \\
(\mathrm{cm})^{*}\end{array}$ & $\begin{array}{l}\text { Shoot length } \\
(\mathrm{cm})^{*}\end{array}$ & $\begin{array}{l}\text { Germination } \\
(\%)^{*}\end{array}$ & Vigour index \\
\hline 1. & $\begin{array}{l}\text { T. ovalisporum } \\
\text { (KU904456) }\end{array}$ & 6.39 & $0.90(1.18)$ & $60.00(50.76)$ & 384.25 \\
\hline 2. & $\begin{array}{l}\text { T. harzianum } \\
\text { (KU933468) }\end{array}$ & 7.02 & $1.10(1.26)$ & 86.67 (72.08) & 596.82 \\
\hline 3. & $\begin{array}{l}\text { T. atroviride } \\
\text { (KU933472) }\end{array}$ & 5.09 & $0.84(1.15)$ & $53.33(46.92)$ & 292.78 \\
\hline 4. & $\begin{array}{l}\text { T. harzianum } \\
\text { (KU933474) }\end{array}$ & 6.92 & $1.05(1.24)$ & $80.00(63.43)$ & 517.58 \\
\hline 5. & $\begin{array}{l}\text { T. asperellum } \\
\text { (KU933475) }\end{array}$ & 4.69 & $0.83(1.15)$ & 46.67 (43.07) & 251.52 \\
\hline 6. & $\begin{array}{l}\text { Hypocrea lixii } \\
\text { (KX0113223) }\end{array}$ & 4.33 & $0.80(1.14)$ & $60.00(51.14)$ & 279.73 \\
\hline 7. & Control & 3.18 & $0.38(0.93)$ & $33.33(35.01)$ & 143.89 \\
\hline
\end{tabular}

*Mean of three replications

Values in parentheses are angular and square root transformed values

Table.4 Effect of Trichoderma isolates on yield and yield attributing characters pod blight of soybean under field condition during 2015-2016

\begin{tabular}{|c|c|c|c|c|c|c|c|c|}
\hline \multirow{2}{*}{$\begin{array}{l}\text { Sl. } \\
\text { No. }\end{array}$} & \multirow{2}{*}{$\begin{array}{c}\text { Treatment } \\
\text { (Trichoderma } \\
\text { spp.) }\end{array}$} & \multirow{2}{*}{$\begin{array}{l}\text { Germin } \\
\text { ation } \\
(\%) *\end{array}$} & \multicolumn{3}{|c|}{ Canopy area $\left(\mathrm{cm}^{2}\right) *$} & \multirow{2}{*}{$\begin{array}{l}\text { No. of } \\
\text { pods/ } \\
\text { plant * }\end{array}$} & \multirow{2}{*}{$\begin{array}{l}\text { No. of } \\
\text { seeds/ } \\
\text { pod } *\end{array}$} & \multirow{2}{*}{$\begin{array}{c}\text { Yield } \\
\text { (q/ha) * }\end{array}$} \\
\hline & & & 30 DAP & 60 DAP & 90 DAP & & & \\
\hline 1. & $\begin{array}{l}\text { T. ovalisporum } \\
\text { (KU904456) }\end{array}$ & $\begin{array}{c}74.60 \\
(59.79)\end{array}$ & 30.27 & 149.96 & 721.58 & 35.23 & 2.67 & 15.11 \\
\hline 2. & $\begin{array}{l}\text { T. harzianum } \\
\text { (KU933468) }\end{array}$ & $\begin{array}{c}87.64 \\
(69.52)\end{array}$ & 38.74 & 225.37 & 835.48 & 46.41 & 3.00 & 17.44 \\
\hline 3. & $\begin{array}{l}\text { T. atroviride } \\
\text { (KU933472) }\end{array}$ & $\begin{array}{c}75.53 \\
(60.42)\end{array}$ & 35.72 & 196.82 & 773.49 & 42.69 & 2.13 & 16.57 \\
\hline 4. & $\begin{array}{l}\text { T. harzianum } \\
\text { (KU933474) }\end{array}$ & $\begin{array}{c}85.22 \\
(67.92)\end{array}$ & 37.50 & 220.40 & 800.19 & 44.89 & 3.00 & 17.11 \\
\hline 5. & $\begin{array}{l}\text { T. asperellum } \\
\text { (KU933475) }\end{array}$ & $\begin{array}{c}76.42 \\
(61.05)\end{array}$ & 28.50 & 152.26 & 729.52 & 37.52 & 2.67 & 15.59 \\
\hline 6. & $\begin{array}{l}\text { Hypocrea lixii } \\
\text { (KX0113223) }\end{array}$ & $\begin{array}{c}77.74 \\
(61.87)\end{array}$ & 29.84 & 185.70 & 759.14 & 38.64 & 2.33 & 16.51 \\
\hline 7. & $\begin{array}{l}\text { Carbendazim- } \\
\text { 50WP }\end{array}$ & $\begin{array}{c}91.00 \\
(72.54)\end{array}$ & 42.52 & 255.62 & 874.81 & 54.63 & 3.00 & 19.50 \\
\hline 8. & Control & $\begin{array}{c}60.64 \\
(51.15)\end{array}$ & 25.32 & 115.40 & 456.18 & 21.68 & 2.00 & 13.02 \\
\hline & S.E(d) \pm & 3.06 & 1.03 & 25.45 & 36.32 & 1.02 & 0.48 & 0.31 \\
\hline & C.D. (5\%) & 6.56 & 2.21 & 54.60 & 77.91 & 2.20 & NS & 0.67 \\
\hline
\end{tabular}

*Mean of three replication

Values in parentheses are angular transformed values 
Int.J.Curr.Microbiol.App.Sci (2018) 7(11): 148-159

Table.5 Effect of Trichoderma isolates on incidence of pod blight of soybean under field condition during 2015-2016

\begin{tabular}{|c|c|c|c|c|c|c|c|}
\hline \multirow{2}{*}{$\begin{array}{l}\text { Sl. } \\
\text { No. }\end{array}$} & \multirow{2}{*}{$\begin{array}{c}\text { Treatment } \\
\text { (Trichoderma } \\
\text { spp.) }\end{array}$} & \multicolumn{5}{|c|}{ Disease incidence (\%) under field experiment * } & \multirow{2}{*}{$\begin{array}{c}\text { Average } \\
\text { disease } \\
\text { incidence } \\
\text { (per cent) }\end{array}$} \\
\hline & & 30 DAP & 45 DAP & 60 DAP & 75 DAP & 90 DAP & \\
\hline 1. & $\begin{array}{l}\text { T. ovalisporum } \\
\text { (KU904456) }\end{array}$ & $2.40(1.70)$ & $5.92(2.53)$ & $12.03(3.54)$ & $19.63(4.49)$ & $29.62(5.49)$ & $13.92(3.55)$ \\
\hline 2. & $\begin{array}{l}\text { T. harzianum } \\
\text { (KU933468) }\end{array}$ & $1.18(1.30)$ & $4.44(2.22)$ & $8.51(3.00)$ & $15.92(4.05)$ & $24.81(5.03)$ & 10.97 \\
\hline 3. & $\begin{array}{l}\text { T. atroviride } \\
\text { (KU933472) }\end{array}$ & & 5 . & & 17. & 27. & $12.46(3.3$ \\
\hline 4. & $\begin{array}{l}\text { T. harzianum } \\
\text { (KU933474) }\end{array}$ & 42) & $4.63(2.26)$ & 09) & 16.66 & $25.92(5.14)$ & $11.56(3.21$ \\
\hline 5. & $\begin{array}{l}\text { T. asperellum } \\
\text { (KU933475) }\end{array}$ & 4) & & & 1 & 9) & 0.4 \\
\hline 6. & $\begin{array}{l}\text { Hypocrea lixii } \\
\text { (KX0113223) }\end{array}$ & $1.85(1.53)$ & $5.18(2.38)$ & $10.00(3.24)$ & $18.51(4.36)$ & $28.14(5.35)$ & $12.73(3.3$ \\
\hline 7. & $\begin{array}{l}\text { Carbendazim- } \\
\text { 50WP }\end{array}$ & 0.92 & 3.33 & 84) & 13.88 & $20.00(4.53)$ & $9.14(2.86)$ \\
\hline 8. & Control & $3.33(1.95)$ & 1.220 & 11.40 & 29.2 & 43.33 & 20.11 \\
\hline & S.E(d) \pm & 0.08 & 0.04 & 0.02 & 0.04 & 0.05 & 0.20 \\
\hline & C.D. (5\%) & 0.17 & 0.11 & 0.06 & 0.10 & 0.11 & 0.43 \\
\hline
\end{tabular}

*Mean of three replication

*** Mean of five replication

Values in parentheses are square root transformed

Fig.1 DNA amplification shown by ITS1 and ITS4 primers of Fusarium sp. Where M: Molecular marker (100bp ladder in size)

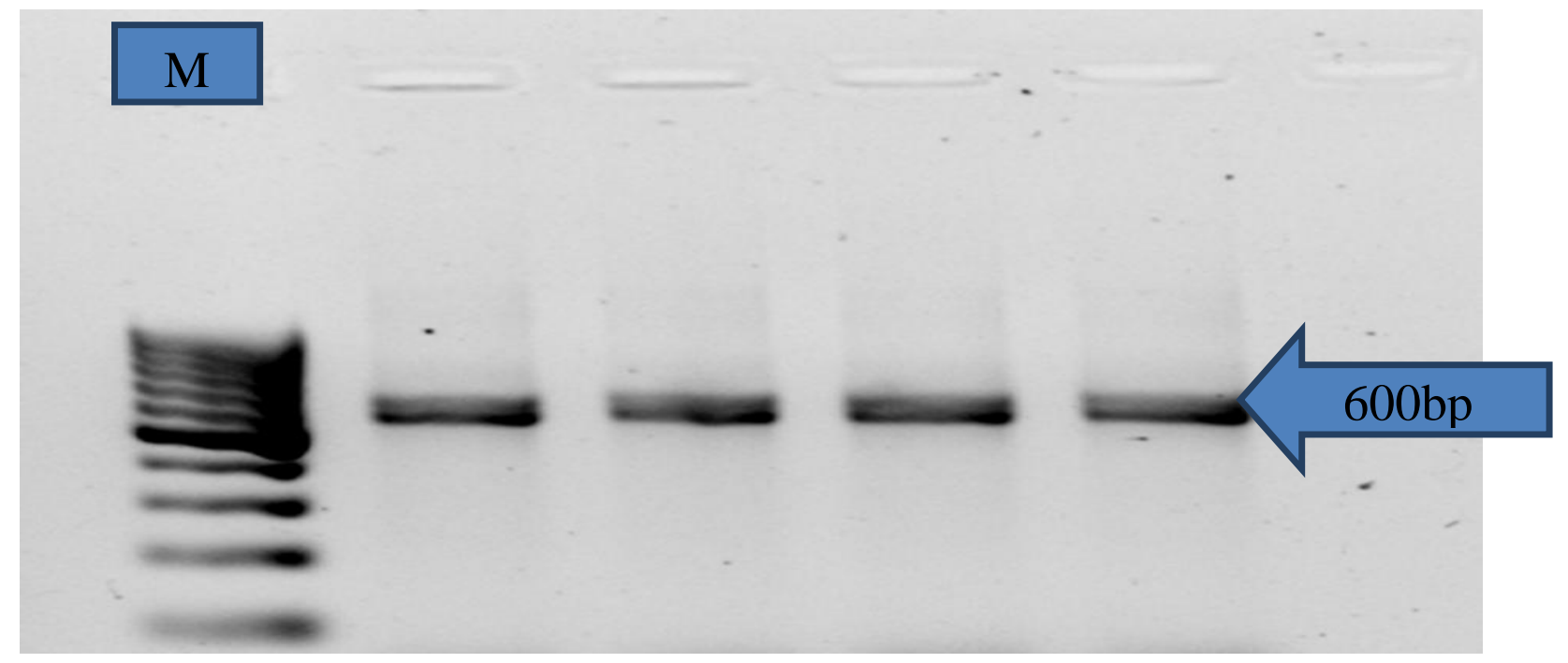


Fig.2 Biopriming of soybean seeds with Trichoderma isolates

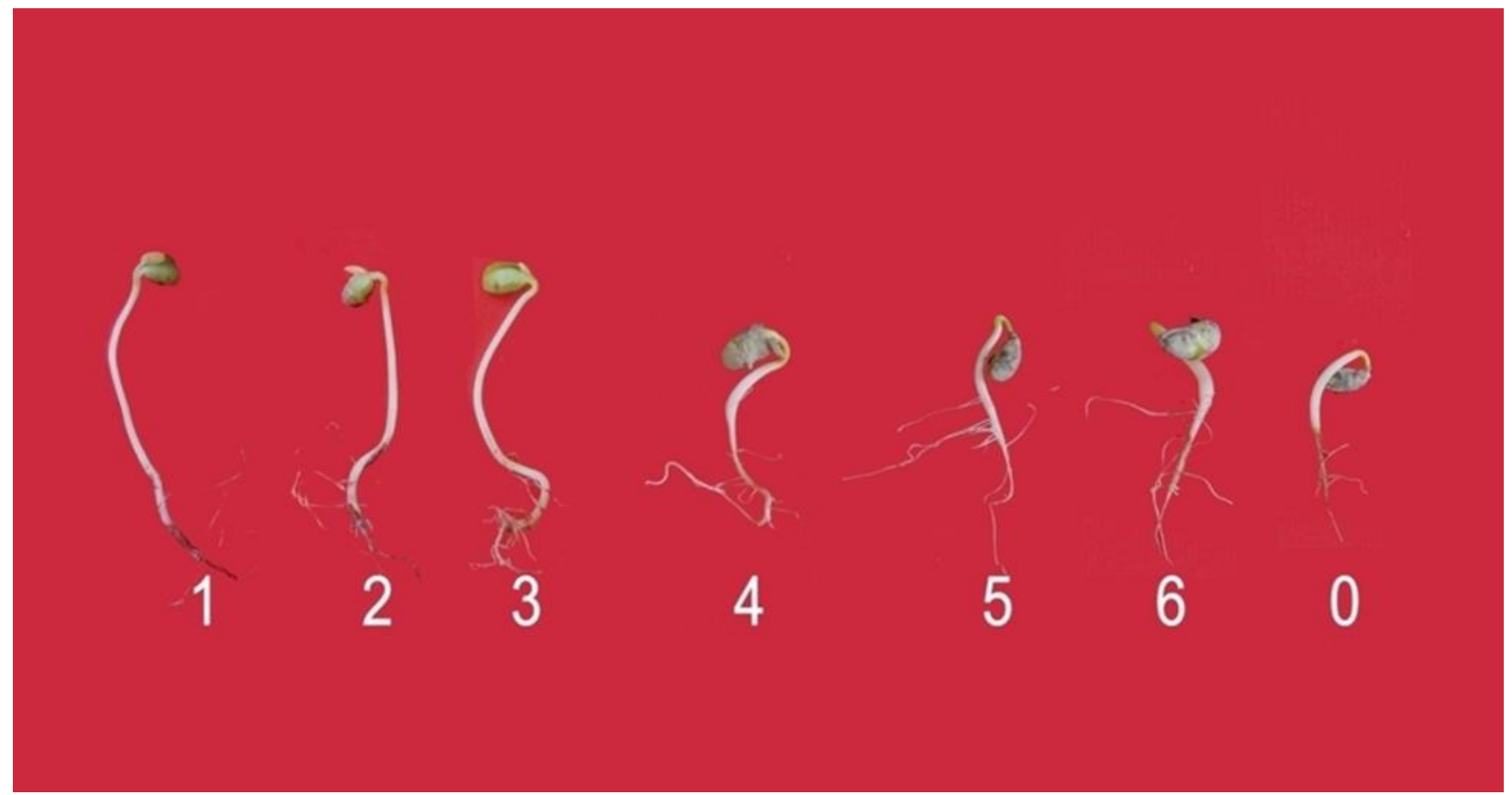

0 - Control, 1 - T. harzianum (KU933468), 2 - T. harzianum (KU933474), 3 - T. ovalisporum (KU904456), 4 - T. atroviride (KU933472), 5 - Hypocrea lixii (KX0113223), 6 - T. asperellum (KU9334472).

\section{Disease incidence}

Data generated on the effect on Trichoderma isolates are presented in table 5. It is evident from the table that percentages of disease incidence were varied among the treatment. At 30 days after planting, disease incidence ranged from $0.92-3.33 \%$. Disease incidence ranged from 3.33-7.22\%, 7.59-17.40\%, 13.88$29.25 \%, 20-43.33 \%$ at 45DAP, 60DAP, 75DAP, 90DAP respectively.

Average disease incidence was found to be lowest at Carbendazim-50WP (9.14\%) followed by Trichoderma isolates viz., T. harzianum - KU933468 (10.97\%), $T$. harzianum- KU933474 (11.56\%), $T$. atroviride- KU933472 (12.46\%), Hypocrea lixii - KX0113223 (12.73\%), T. asperellum KU933475 (13.26\%), T. ovalisporum KU904456 (13.92\%). However, in untreated control plot, the average disease incidence was found to be $20.11 \%$.

\section{Plant canopy}

Plant canopy of each treatment of five randomly selected and tagged plants were measured at 30, 60 and 90 days after planting from East-West and North-South direction and result were presented in table 4. Results showed that canopy area of plants treated with Carbendazim-50WP was higher than those treated with Trichoderma isolates. Canopy area was ranged from $25.32-42.52 \mathrm{~cm}^{2}$, $115.40-255.62 \mathrm{~cm}^{2}$ and $456.18-874.81 \mathrm{~cm}^{2}$ at 30DAP, 60DAP and 90DAP respectively.

\section{Number of pods per plant}

Effect of different treatments on the yield parameters of soybean are presented in table 4. Among the different treatments, Carbendazim-50WP was found to have the highest numbers of pod per plant (54.63). Among the isolates of Trichoderma spp. $T$. harzianum (KU933468) was found to have the highest number of pods per plant (46.41) 
and lowest in T. ovalisporum - KU904456 (35.23). However, in untreated control plot the number of pods per plant was 21.68.

\section{Number of seeds per pod}

There was no significant treatment difference among the treatment on the number of seeds per pod. However, highest number of seeds per pod i.e. 2.74 nos. of seeds per pod was found in Carbendazim-50WP treated plot as presented in table 4.

\section{Yield}

Results on effects of potent Trichoderma isolates and chemical on the yield of soybean under field experiment are presented in table 4. Results indicated that highest yield of 19.50 $\mathrm{q} / \mathrm{ha}$ were obtained in Carbendazim-50WP treated plot. Among the Trichoderma isolates, T. harzianum - KU933468 treated plot gave the highest yield $(17.44 \mathrm{q} / \mathrm{ha})$ followed by $T$. harzianum- KU933474 (17.11 q/ha), $T$. atroviride- $\quad$ KU933472 (16.57 q/ha), Hypocrea lixii - KX0113223 (16.51 q/ha), T. asperellum - KU933475 (15.59 q/ha) $T$. ovalisporum- KU904456 (15.11 q/ha) respectively. Lowest yield of $13.02 \mathrm{q} / \mathrm{ha}$ was observed in control plot. Likewise there are several reports of biocontrol of plant pathogens in vivo and in vitro conditions against seed borne diseases (Patel and Joshi, 2001; Ramamoorthy and Samiyappan, 2001; Ingle et al., 2002; Raheja and Thakore, 2002; Rao and Narayana, 2005) Similarly, Prasad et al., (2002) reported that biopriming with Trichoderma resulted into increased germination percentage, root and shoot length of red gram under field condition.

\section{Acknowledgement}

The authors express sincere thanks to H.O.D. of Plant Pathology, College of Agriculture, Central Agricultural University, Imphal, Dean and college authorities of CAU, Imphal for providing all the necessary materials and technical help during the experimental period.

\section{References}

Altinok, H.H. and Erdogan, O. 2015. Determination of the in vitro effect of Trichoderma harzianum on phytopathogenic strains of Fusarium oxysporum. Not. Bot. Horti. Agrobo, 43(2): 494-500.

Anonymous. 2016. Crop production summary, National Agriculture Statistics Service, United States Department of Agriculture.

Bennett, M.A., Fritz, V.A. and Callan, N.W. 1992. Impact of seed treatments on crop stand establishment. Hortic. Tech., 2: 345-349.

Bhatnagar, P.S. 1997. An overview of soybean in India strategies for augmenting productivity and production with special reference to combating soybean rust, in: Global focus on soybean and crop outlook for India. Soybean Kharif, 1997-98. SOPA, Indore.

Chavan, S.S. and Dhutraj, D.N. 2017. Proceedings of $67^{\text {th }}$ IRF International Conference, 8th January, 2017, Pune, India, ISBN: 978-93-86291-94-3.

Chet, I. and Inbar, J. 1994. Biological control of fungal pathogens. Appl. Biochem. Biotechnol., 48: 37-43.

Dennis, C. and Webster, J. 1971a. Antagonists properties of species groups of Trichoderma 1. Production of nonvolatile antibiotics. T. Brit. Mycol. Soc., 57: 25-39.

Dennis, C. and Webster, J. 1971b. Antagonistic properties of species groups of Trichoderma 11. Production of volatile antibiotics. T. Brit. Mycol. Soc., 57: 41-48. 
Devi, D.N., Venkataramann, M., Srivastava, R.K., Uppalapati, S.R., Gupta, V.K., Yli-Muttila, T., Tsui, K.M.C., Srinivas, C., Niranjana, S.R. and Chandra, N.S. 2016. Molecular phylogeny, pathogenicity and toxigenicity of Fusarium oxysporum f.sp. lycopersici. Science Report, 6: 213-267.

Doijode, S.D. 2006. Seed quality in vegetable crops A.S. Basra (Ed.). Handbook of Seed Science and Technology, Food product press. An imprint of Haworth Press Inc., New York, London, Oxford. Pp. 677-701.

Garcia, E.F. 1991. Screening of fungal antagonist to control Sclerotium cepivorium. In: Jensen et al., (eds). New approaches in biological control of soil borne diseases. IOBCM/PRS Bull. Cph., pp. 79-81.

Harman, G.E., Jin, X., Stasz, T.E., Peruzzotti, G., Leopold, A.C. and Taylor, A.G. 1991. Production of conidial biomass of Trichoderma harzianum for biological control. Biol. Cont., 1: 23-28.

Ingle, Y.V., Ingle, R.W. and Jamade, S.R. 2002. In vitro studies on leaf spot of turmeric caused by C. capsici. Pl. Dis. Res., 17(1): 217.

Iturritxa, E., Slippers, B., Mesanza, N. and Wingfield, M.J. 2011. First report of Neofusicoccum parvum causing canker and die back of Eucalyptus in Spain. Australasian Plant Disease Notes, DOI 10.1007/s13314-011-0019-5.

Mittal, R.K., Prakash, V. and Koranne, K.D. 1993. Package of practices for the cultivation of pulses in the hills of the Uttar Pradesh. Indian Farming, 42(10): 3-5.

Patel, R.V. and Joshi, K.R. 2001. Antagonistic effects of some bio agents in vitro against $C$. gloeosporoides Penz and Sace the causal agent of leaf spot of turmeric. J. Mycol. Pl. Pathol., 31(1): 126-128.
Prasad, R.D., Rangeshwaran, R., Anuroop, C.P. and Rashni, H.J. 2002. Biological control of wilt and root rot of chickpea under field conditions. Ann. Pl. Prot. Sci., 10(1): 72-75.

Raheja, S. and Thakore, B.B.L. 2002. Effect Of the physical factors, plant extracts and bioagents on Colletotrichum gloesporioides causing anthracnose in Yam. J. Mycol. Pl. Pathol., 32(2): 282287.

Ramamoothy, V. and Samiyappan, R. 2001. Induction of defence related genes in Pseudomonas afluorescens treated chilli plants in response to infection by Colletotrichum capsici. J. Mycol. Pl. Pathol., 31(2): 146-155.

Rao, C.H. and Narayana, Y.D. 2005. In vitro evaluation of fungicides, plant extracts and biocontrol agents against $C$. dematium the causal organism of Chickpea (Cicer arietenum L.) blight. In national symposium on crop disease management in dry land Agril. And $57^{\text {th }}$ Annual meeting IPS, Jan. 12-14, 2005, MAU, Parbhani.

Raza, W., Faheem, M., Yousaf, S., Rajer, F.U. and Yameen, M. 2013. Volatile and non-volatile antifungal compounds produced by Trichoderma harzianum SQR-T037 suppressed the growth of Fusarium oxysporum f.sp. niveum. Sci. Lett., 1(1): 21-24.

Sarabhoy, A.K. and Agarwal, D.K. 1983. Fungal diseases of soybean and their management. Int. J. Trop. Pl. Dis., 1: 13-19.

Sinclair, J.B. 1992. Discoloration of soybean seeds an indicator of quality. Pl. Dis., 76(11): 1087-1091.

White, T., Bruns, T., Lee, S., and Taylor, J. 1990. Amplification and direct sequencing of fungal ribosomal RNA genes for phylogenetics. In: Innis, M.A., Gelfand, D.H., Sninskry, J.J. and White, 
T.J. (Eds.) PCR protocols, a guide to methods and applications, New York: Academic Press, pp. 315-322.

Wrather, J.A., Anderson, T.R., Arsyad, D.M., Tan, Y., Ploper, L.D., Porta, A., Ram,
H.H., Yorinori, J.T. 2001. Soybean diseases losses estimates for the top ten soybean producing countries in 1998. Can. J. of Pl. Pathol., 23: 115-121.

\section{How to cite this article:}

Lalhruaitluangi, C., B. Sinha and Tusi Chakma. 2018. Occurrence of Fusarium oxysporum (Schlecht. Emend. Snyder \& Hansen) Causing Pod Blight of Soybean (Glycine max L.) and Its Suitable Management with Native Trichoderma spp. in Manipur, India.. Int.J.Curr.Microbiol.App.Sci. 7(11): 148-159. doi: https://doi.org/10.20546/ijcmas.2018.711.019 